\title{
Characterization of Perchlorate-Removal Using Elemental Sulfur Granules and Activated Sludge
}

\author{
Kyoung-Rim Han ${ }^{1,2}$ and Yeonghee Ahn ${ }^{1}$ * \\ ${ }^{1}$ Department of Environmental Engineering Dong-A University, Busan 604714, Korea \\ ${ }^{2}$ Busan Center, Korea Basic Science Institute, Busan 609-735, Korea
}

Received April 1, 2013 /Revised May 8, 2013 /Accepted May 20, 2013

\begin{abstract}
Perchlorate $\left(\mathrm{ClO}_{4}^{-}\right)$is an emerging contaminant found in surface water and soil/groundwater. Microbial removal of perchlorate is the method of choice since perchlorate-reducing bacteria (PRB) can reduce perchlorate to harmless end-products. A previous study [3] showed experimental evidence of autotrophic perchlorate removal using elemental sulfur granules and activated sludge. The granular sulfur is a relatively inexpensive electron donor, and activated sludge is easily available from a wastewater treatment plant. A batch test was performed in this study to further investigate the effect of various environmental parameters on the perchlorate degradation by sludge microorganisms when elemental sulfur was used as electron donor. Results of the batch test suggest optimum conditions for autotrophic perchlorate degradation by sludge microorganisms. The results also show that sulfur-oxidizing PRB enriched from activated sludge removed perchlorate better than activated sludge. Taken together, this study suggests that autotrophic perchlorate removal using elemental sulfur and activated sludge can be improved by employing optimized environmental conditions and enrichment culture.
\end{abstract}

Key words : Autotroph, activated sludge, elemental sulfur granules, optimization, perchlorate

\section{서 론}

퍼클로레이트(perchlorate, $\mathrm{ClO}_{4}^{-}$)는 지표수, 지하수 및 토양 의 신규 오염물이다. $\mathrm{ClO}_{4}^{-}$의 발생원은 대부분 일상생활에 사 용되는 제품(예, 건전지, 자동차 에어백, 페인트, 의약품, 비료 제조 등) 및 화약류의 제조공정이다. 특히 LCD 제조공정의 세정제나 아연제련 공정에서 배출되는 폐수가 우리나라에서 $\mathrm{ClO}_{4}^{-}$의 오염원으로서 주로 보고되었다 $[4,6,9]$.

$\mathrm{ClO}_{4}^{-}$은 80여개의 다른 염의 형태로 생산되며, 이 중에서 미국에서는 $\mathrm{NH}_{4} \mathrm{ClO}_{4}$ 가 생산량의 $90 \%$ 이상을 차지한다[4]. $\mathrm{ClO}_{4}^{-}$은 비휘발성이고 물에서 화학적으로 안정하며 용해도가 높아 광범위 오염을 초래할 수 있다: $20^{\circ} \mathrm{C}$ 에서 $\mathrm{NaClO}_{4}$ 와 $\mathrm{NH}_{4} \mathrm{ClO}_{4}$ 의 용해도는 각각 $2,010 \mathrm{~g} / 1$ 와 $209 \mathrm{~g} / 1$ 이다[13]. $\mathrm{ClO}_{4}^{-}$ 는 인체에 흡수되면 갑상선에 요오드가 흡수되는 것을 막아 갑상선호르몬 생성을 방해하고 성장과 물질대사를 저해하므 로 인체에 전반적인 영향을 미친다[10, 14].

2006년에 낙동강 수계와 부산시 수돗물에 $\mathrm{ClO}_{4}{ }^{-}$가 고농도 로 검출되면서 이 화합물에 대한 환경문제가 우리나라에서

\footnotetext{
*Corresponding author

Tel : +82-51-200-7677, Fax : +82-51-200-7683

E-mail : yahn@dau.ac.kr

This is an Open-Access article distributed under the terms of the Creative Commons Attribution Non-Commercial License (http://creativecommons.org/licenses/by-nc/3.0) which permits unrestricted non-commercial use, distribution, and reproduction in any medium, provided the original work is properly cited.
}

대두되었다[17]. 그 이 후 2007년 12월에 '수질 및 수생태계 보전에 관한 법률 시행규칙 일부 개정령안' [15]에 따라 $\mathrm{ClO}_{4}{ }^{-}$ 를 수질오염물질로 지정하고, $\mathrm{ClO}_{4}^{-}$의 배출허용기준이 입법예 고 되었으나, 정작 2008년에 $\mathrm{ClO}_{4}^{-}$는 수질오염물질로 신규 지 정되었지만 $\mathrm{ClO}_{4}^{-}$의 배출허용기준은 입법되지 않고 아직 검토 중에 있는 실정이다. $\mathrm{ClO}_{4}^{-}$배출허용기준이 시행되지 않은 주 원인중의 하나는 $\mathrm{ClO}_{4}^{-}$처리기술이 아직 개발이 안되었기 때 문이다. 2010년에는 $\mathrm{ClO}_{4}^{-}$가 먹는물 수질감시항목으로 지정됨 에 따라 권고기준 $15 \mu \mathrm{g} \mathrm{ClO}_{4}^{-} / 1$ 이 설정되었고, 그 이후부터 분기별로 한번씩 검사를 실시하고 있다[16]. 감시항목은 먹는 물 수질기준이 설정되기 전에 먹는물의 안전성을 확보하기 위해 먹는물에 포함된 함유실태조사 등 모니터링을 지속적으 로 실시하는 물질이다.

수질오염물질인 $\mathrm{ClO}_{4}^{-}$가 하수처리장과 정수장에서 어느 정 도 제거되는지 연구한 보고에 따르면 기존의 활성슬러지 (activated sludge) 공정만을 이용하는 하수처리장에서는 $\mathrm{ClO}_{4}^{-}$제거가 거의 되지 않는 것으로 보고되었다[8]. 또한 정수 장의 고도처리시설에서는 활성탄의 사용시간 증가에 따라 흡 착능의 초과로 인해 원수보다 오히려 처리수에 $\mathrm{ClO}_{4}^{-}$농도가 높게 검출되었다[7]. 그래서 $\mathrm{ClO}_{4}^{-}$는 배출원인 개별업체에서 제거하는 대책이 필요하다. 즉 하수처리장 또는 정수장에서 제거하는 것 보다는 이런 처리 시설로 유입되기 전 단계에서 처리하는 것이 바람직하다.

$\mathrm{ClO}_{4}^{-}$제거는 물리화학적 방법과 또는 생물학적 방법으로 구분될 수 있다. 한 매질에서 다른 매질로 단순히 $\mathrm{ClO}_{4}^{-}$를 이동 
시키는 물리화학적 처리에 비해 미생물을 이용한 생물학적 처리는 $\mathrm{ClO}_{4}^{-}$를 무해한 산물로 완전히 전환하므로 친환경적이 며 경제적이다. $\mathrm{ClO}_{4}^{-}$를 분해하는 미생물은 $\mathrm{ClO}_{4}^{-}$을 환원하는 세균(perchlorate-reducing bacteria, PRB)이다[10]. PRB는 $\mathrm{ClO}_{4}^{-}$를 chlorate $\left(\mathrm{ClO}_{3}^{-}\right)$와 chlorite $\left(\mathrm{ClO}_{2}^{-}\right)$로 순차적으로 환원 시키고 최종적으로 chloride $(\mathrm{Cl})$ 로 전환한다: 식 1.

$$
\mathrm{ClO}_{4}^{-} \rightarrow \mathrm{ClO}_{3}^{-} \rightarrow \mathrm{ClO}_{2}^{-} \rightarrow \mathrm{Cl}^{-}+\mathrm{O}_{2}
$$

종속영양 $\mathrm{PRB}$ 를 이용한 기존의 연속적 $\mathrm{ClO}_{4}^{-}$제거법은 유 기물(예, 초산, 에탄올 등)을 지속적으로 미생물에게 공급해야 하므로 비용이 높을 뿐더러 미생물의 과다성장에 따른 biomass에 의한 반응기의 막힘 현상이 심하여 공정상에 문제를 초래하는 것으로 알려졌다 $[2,10]$. 종속영양 방식에 의한 $\mathrm{ClO}_{4}^{-}$ 처리에 따른 이러한 문제점을 해결하기 위해 수소기체 $\left(\mathrm{H}_{2}\right)$ 를 전자 공여체로 사용하고 $\mathrm{CO}_{2}$ 를 탄소원으로 사용하는 독립영 양 PRB를 이용하는 연구가 보고되었다[11, 12]. 이 연구결과에 서는 biomass에 의한 막힘 현상이 덜하고 유기물을 지속적으 로 공급해줄 필요성이 없으므로 처리 비용도 비교적 저렴한 것으로 보고되었다. 그러나 $\mathrm{H}_{2}$ 는 취급과 저장에 폭발의 위험 성이 있어 현장규모로 적용하는 것은 제한되었다. 그래서 안 전하고 경제적인 전자 공여체를 사용한 $\mathrm{ClO}_{4}^{-}$제거법이 개발 될 필요가 있다.

원소 황(elemental sulfur, $\mathrm{S} 9$ 이 물에서 산화되면 식 2와 같 은 반응이 일어나고, 황을 산화하는 미생물이 $\mathrm{ClO}_{4}{ }^{-}$를 전자수 용체로 사용할 경우 식 3 과 같은 반응이 일어난다:

$$
\begin{aligned}
& \mathrm{S}^{0}+4 \mathrm{H}_{2} \mathrm{O} \rightarrow \mathrm{SO}_{4}^{2-}+8 \mathrm{H}^{+} \\
& 3 \mathrm{ClO}_{4}^{-}+4 \mathrm{~S}^{0}+4 \mathrm{H}_{2} \mathrm{O} \rightarrow 3 \mathrm{Cl}^{-}+4 \mathrm{SO}_{4}^{2-}+8 \mathrm{H}^{+}
\end{aligned}
$$

원소 황입자(sulfur granule)를 독립영양 $\mathrm{PRB}$ 가 전자 공여 체로 사용하여 $\mathrm{ClO}_{4}^{-}$를 제거할 경우, 값비싼 유기물이나 폭발 의 위험이 있는 $\mathrm{H}_{2}$ 를 공급할 필요가 없기 때문에 비교적 저렴 하고 안전하게 전자 공여체를 제공할 수 있을 뿐만 아니라, 황입자 자체를 담체로 활용할 수는 장점이 있으므로 $\mathrm{ClO}_{4}^{-}$처 리비용을 줄일 수 있을 것이다.

한경림 등[3]은 원소 황을 이용하는 PRB가 활성슬러지에 존재한다는 실험적 증거를 보고함으로써 저렴한 비용으로 효 율적으로 $\mathrm{ClO}_{4}^{-}$를 제거할 수 있는 가능성을 제시하였다. 그래 서 본 연구에서는 원소 황을 이용하는 활성슬러지의 PRB에 의한 $\mathrm{ClO}_{4}^{-}$분해를 향상시키기 위한 방안을 모색하기 위해 $\mathrm{ClO}_{4}^{-}$분해에 영향을 주는 환경요인들을 회분 반응실험을 통 해 조사하였다.

\section{재료 및 방법}

접종균과 시약

회분반응 실험에 접종 미생물로서 사용한 활성슬러지는 부
산시 하수처리장(부산시 환경시설공단 강변사업소)에서 채취 한 잉여슬러지를 사용하였다. 채취한 슬러지는 접종하기 전에 동일 부피의 mineral medium을 사용하여 3번 세척하여 슬러 지액에 잔존하는 용해된 유기물이나 $\mathrm{Cl}^{-}$를 제거한 후 실험에 사용하였다.

Mineral medium의 조성(1 당)은 다음과 같다: $2 \mathrm{mg} \mathrm{MgSO}_{4}$. $7 \mathrm{H}_{2} \mathrm{O}, 47 \mathrm{mg} \mathrm{K}_{2} \mathrm{HPO}_{4}, 27 \mathrm{mg} \mathrm{NaH}_{2} \mathrm{PO}_{4} \cdot \mathrm{H}_{2} \mathrm{O}, 16 \mathrm{mg}$ $\mathrm{NH}_{4} \mathrm{H}_{2} \mathrm{PO}_{4}, 1 \mathrm{~g} \mathrm{NaHCO}$, 40 ug NiCl$\cdot 6 \mathrm{H}_{2} \mathrm{O}, 40 \mu \mathrm{g} \mathrm{Na} \mathrm{SeO}_{3}$. $5 \mathrm{H}_{2} \mathrm{O}$. 배지는 초순수(ultrapure water)를 사용하여 제조하였 으며 언급이 없는 한 mineral medium의 초기 $\mathrm{pH}$ 는 7.43 이었 다. 본 연구에 사용된 sodium perchlorate $\left(\mathrm{NaClO}_{4}\right.$, 순 도>99\%)는 ACROS Organics (New Jersey, USA)에서 구입하 였다. 한편 입자상 원소 황 $\left(\mathrm{S}^{0}\right.$, 순도>99.98\%; 지름 2-3 mm)은 (주미원상사(한국, 울산)에서 구입하였다. 그 외 시약들은 모두 Sigma-Aldrich Chemical Company, Inc. (St. Louis, MO, USA)로부터 구입하였으며 가장 순도(순도>99\%)가 높은 것이 었다.

\section{회분배양}

원소황을 전자공여체로 이용하는 활성슬러지 내의 PRB가 $\mathrm{ClO}_{4}^{-}$를 분해하는 최적 분해조건을 찾기 위해 다양한 초기 변 수 $\left(\mathrm{pH}, \mathrm{ClO}_{4}^{-}\right.$농도, 배양온도, biomass 농도, 그리고 접종균의 종류)를 적용하여 회분배양 실험을 실시하였다(Table 1). 모든 실험은 triplicate로 실시하였다. 달리 언급이 없는 한 배양액의 초기 $\mathrm{pH} 7.43$, 초기 $\mathrm{ClO}_{4}^{-}$농도 $37.65 \pm 0.8 \mathrm{mg} / \mathrm{l}$, 초기 biomass 농도 $0.04 \mathrm{~g} \mathrm{VSS} / 1$ 로 하였고 접종균은 활성슬러지를 사용하였 다. 초기 $\mathrm{pH}$ 를 조절할 필요가 있을 때는 $1 \mathrm{M} \mathrm{H}_{2} \mathrm{SO}_{4}$ 나 $1 \mathrm{M}$ $\mathrm{NaOH}$ 를 사용하였다.

회분반응기로서는 $100 \mathrm{ml}$ 의 serum bottle을 사용하였으며 반응기 내에는 배지를 포함한 $50 \mathrm{ml}$ 배양액과 $20 \mathrm{~g} / 1$ 의 황 입자를 넣고 butyl rubber와 aluminum crimp로 반응기를 봉

Table 1. Parameters used to optimize perchlorate biodegradation in batch test

\begin{tabular}{cc}
\hline Parameters & Values \\
\hline Culture temperature $\left({ }^{\circ} \mathrm{C}\right)$ & 25 \\
& 30 \\
\hline \multirow{2}{*}{ PH } & 6.35 \\
& 7.43 \\
Perchlorate conc. $(\mathrm{mg} / \mathrm{l})$ & 8.23 \\
\hline \multirow{2}{*}{ Biomass conc. $(\mathrm{g}$ VSS/l) } & 14.07 \\
& 23.37 \\
& 37.91 \\
\hline \multirow{2}{*}{ Inoculum } & 0.02 \\
& 0.04 \\
& 0.08 \\
\hline
\end{tabular}


하였다. 반응기 내부의 산소는 질소기체(99.99\%)로 2 분간 purge하여 제거한 후, 반응기는 $25^{\circ} \mathrm{C}$ 의 어두운 곳에서 진탕 $(150 \mathrm{rpm})$ 배양하였다. $\mathrm{ClO}_{4}^{-}$제거효율은 식 4 에 의해 계산하였 다. 식 4 에서 $\mathrm{C}_{0}$ 는 배양초기의 $\mathrm{ClO}_{4}^{-}$농도이고, 한편 $\mathrm{C}_{\mathrm{t}}$ 는 $\mathrm{t}$ 시간 후의 $\mathrm{ClO}_{4}^{-}$농도이다.

$$
\mathrm{ClO}_{4}^{-} \text {제거효율 }(\%)=\frac{\left(\mathrm{C}_{0}-\mathrm{C}_{\mathrm{t}}\right) \times 100}{\mathrm{C}_{0}}
$$

\section{농화배양(enrichment culture)}

활성슬러지를 구성하는 미생물군집은 다양한 미생물개체 군으로 구성되어있다고 보고되었다[18]. 전 연구[3]의 결과 원 소황과 활성슬러지를 이용해서 $\mathrm{ClO}_{4}^{-}$를 분해할 수 있다는 것 이 실험적으로 증명되었으므로, 황을 산화하는(전자공여체로 이용하는) PRB가 활성슬러지 미생물에 존재함을 알 수 있었 다. 그래서 황산화 PRB의 biomass를 다량 확보하고자 농화배 양을 실시하였다. PRB 농화배양은 문헌[3]에 언급된 것과 같 이 원소 황 입자와 $\mathrm{ClO}_{4}^{-}$를 포함하는 mineral medium에 활성 슬러지를 접종하여 1년 이상 배양한 것이었다.

\section{분석방법}

Biomass 농도 분석은 Standard method [1]에 따라 VSS 측 정을 하였다. 회분반응의 시료는 반응기로부터 주기적으로 채 취하여 $\mathrm{ClO}_{4}^{-}$농도와 $\mathrm{pH}$ 를 분석하였다. 채취한 시료는 syringe filter (pore size, $0.22 \mu \mathrm{m}$ )로 여과 후 필요에 따라서는 적당히 희석하여 ion chromatograph (IC, Dionex ICS-3000; Dionex, Sunnyvale, CA)로 분석하는데 사용하였다. IC 분석은 한국기초과학연구원에서 실시하였으며 $\mathrm{ClO}_{4}^{-}$의 분석은 $\mathrm{EPA}$ METHOD 314.0 [19]을 수정한 방법[3]을 사용하였다. Analytical column AS16 (Dionex, USA)과 guard column AG16 (Dionex, USA)이 장착된 IC (Dionex ICS-3000)을 사용하여 $\mathrm{ClO}_{4}^{-}$농도를 분석하였으며 $\mathrm{ClO}_{4}^{-}$의 검출한계는 $0.5 \mu \mathrm{g} / 1$ 이었 다. IC 분석에 사용한 표준시약은 AccuStandard Inc. (New Haven, $\mathrm{CT}, \mathrm{USA}$ )에서 구매하였다. 한편 시료의 $\mathrm{pH}$ 는 $\mathrm{pH}$ meter (Isteck, 한국)로 측정하였다.

\section{결과 및 고찰}

\section{배양온도의 효과}

입자상 원소황과 활성슬러지미생물을 이용한 회분배양실 험에서 배양온도에 따른 $\mathrm{ClO}_{4}^{-}$의 분해에 대한 영향을 조사하 였다. 두 가지 $\left(25\right.$ 와 $\left.30^{\circ} \mathrm{C}\right)$ 다른 온도에서 반응기를 배양하여 회분배양액내의 잔존하는 $\mathrm{ClO}_{4}^{-}$농도를 분석하였다(Fig. 1). 배 양초기에는 두 온도에서 거의 비슷하게 매우 서서히 분해가 일어났으며, 배양 9 일째부터는 $30^{\circ} \mathrm{C}$ 에서 더 빠르게 분해가 일 어났다. 배양 15 일째에 배양액 내에 잔존하는 $\mathrm{ClO}_{4}^{-}$농도를 측정한 결과 제거효율은 $30^{\circ} \mathrm{C}$ 에서는 $56.6 \%$ 을 나타내었으나

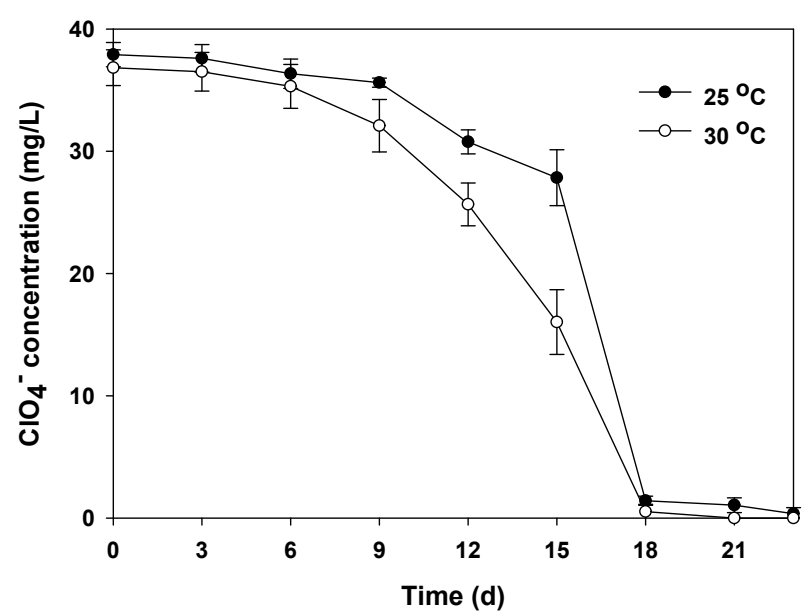

Fig. 1. Effect of culture temperature on perchlorate removal by activated sludge in the presence of sulfur particles. Data are given as mean \pm standard deviation $(n=3)$.

$25^{\circ} \mathrm{C}$ 에서는 $26.6 \%$ 인 것으로 측정되었다. 그러나 배양 18 일째 분석해 본 결과 30 과 $25^{\circ} \mathrm{C}$ 에서 각각 제거효율은 98.6 과 $96.3 \%$ 인 것으로 나타났다. 본 연구의 결과는 온도제어장치가 설치 되지 않은 현장에서 원소황과 활성슬러지를 이용하여 $\mathrm{ClO}_{4}^{-2}$ 를 분해할 경우 현장의 온도에 따라 분해속도가 영향을 받을 수 있다는 것을 나타내었다. 또한 계절에 따른 온도의 영향으로 오염된 환경에서 활성슬러지를 접종해서 $\mathrm{ClO}_{4}^{-}$를 처리할 경우 그 분해속도가 달라질 수 있다는 것을 나타내었다.

본 연구는 활성슬러지와 원소황을 이용한 독립영양방식의 $\mathrm{ClO}_{4}^{-}$분해를 회분반응으로 실험한 결과이다. 본 실험결과와 비교할 수 있는 비슷한 연구인 Ju 등[5]의 보고에 의하면 0.055 $\mathrm{g} \mathrm{VSS} / 1$ 활성슬러지와 원소황(전자공여체)을 사용하여 $30^{\circ} \mathrm{C}$ 에서 회분배양 하였을 때 약 $320 \mathrm{mg} \mathrm{ClO}{ }_{4}^{-} / 1$ 를 22 일만에 완전 분해하였다고 하였다. 그러나 그 실험에 사용된 배지가 유기 성 전자공여체로 작용할 수 있는 yeast extract를 포함하고 있 는 점을 고려하면 전적으로 독립영양방식에 의한 $\mathrm{ClO}_{4}^{-}$제거 의 결과는 아닌 것으로 판단된다.

$\mathrm{ClO}_{4}^{-}$의 생분해에 미치는 온도의 영향은 다른 문헌에서도 보고되었다. 활성슬러지로부터 농화배양된 접종균을 사용하 여 $30^{\circ} \mathrm{C}$ 에서 회분배양 하였을 때 $16^{\circ} \mathrm{C}$ 에서보다 $\mathrm{ClO}_{4}^{-}$를 더 빨 리 분해하였다고 보고하였다[5]. 한편 $\mathrm{Wu}$ 등[20]은 acetate를 전자공여체로 사용하여 활성슬러지로부터 농화배양된 $\mathrm{PRB}$ 를 접종하여 $30^{\circ} \mathrm{C}$ 에서 회분배양 하였을 때 $20^{\circ} \mathrm{C}$ 에서보다 $\mathrm{ClO}_{4}^{-}$를 더 빨리 분해하였다고 보고하였다.

\section{초기 $\mathrm{pH}$ 의 효과}

회분배양실험에서 배양액의 초기 $\mathrm{pH}$ 에 따른 $\mathrm{ClO}_{4}{ }^{-}$의 생분 해에 대한 영향을 조사하였다. 배양액의 초기 $\mathrm{pH}$ 를 $6.35,7.43$ 그리고 8.23 으로 각각 달리하여 배양한 후 주기적으로 배양액 의 $\mathrm{ClO}_{4}^{-}$농도를 분석하였다(Fig. $2 \mathrm{~A}$ ). 배양액의 초기 $\mathrm{pH}$ 가 

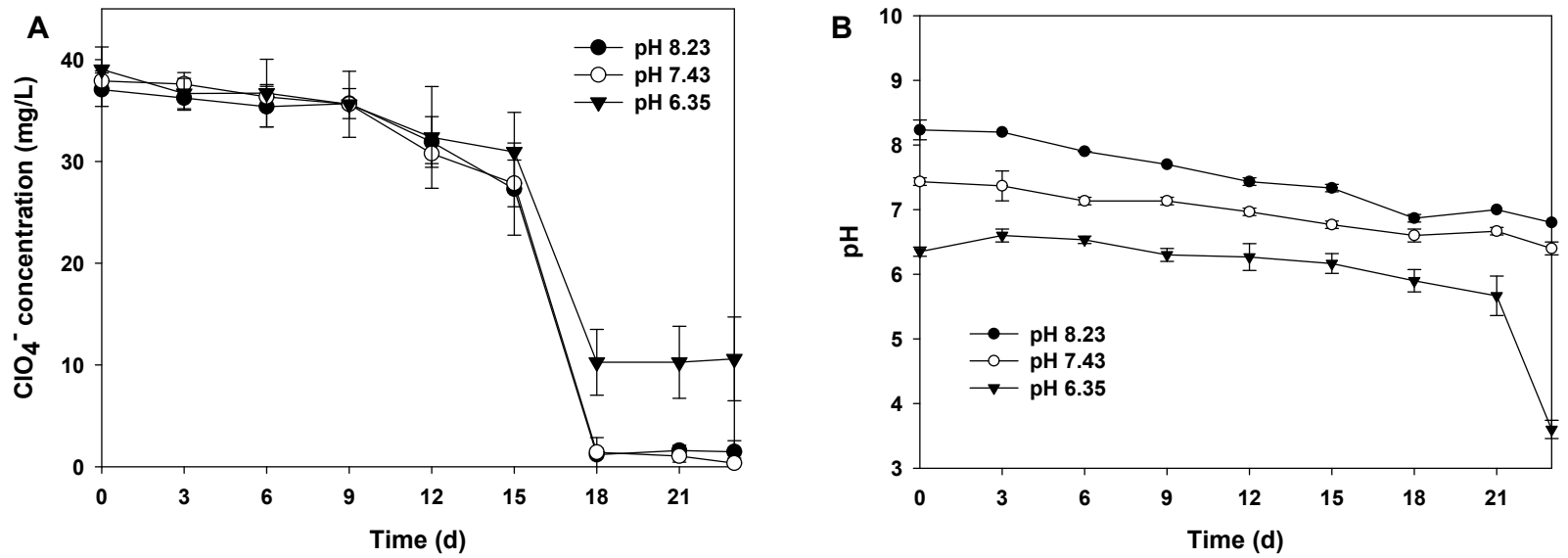

Fig. 2. Effect of initial $\mathrm{pH}$ on perchlorate removal by activated sludge in the presence of sulfur particles. Perchlorate concentration (A) and $\mathrm{pH}$ changes (B) of the culture with time. Data are given as mean \pm standard deviation $(\mathrm{n}=3)$.

각각 7.43 와 8.23 인 반응기들은 $\mathrm{ClO}_{4}^{-}$를 제거하는 경향이 거의 비슷하게 나타났다. 배양 초기 9일까지는 매우 서서히 분해가 일어나다가 9일이 지나서야 $\mathrm{ClO}_{4}^{-}$농도가 다소 감소하다가 배 양 15 일 후 급격히 농도가 감소하는 경향을 보였다. 반면에 배양액의 초기 $\mathrm{pH}$ 가 6.35 일 때는 15 일까지는 매우 서서히 분해가 일어나다가 배양 15 일 이후 급격히 농도가 감소하다가 18 일부터는 더 이상 $\mathrm{ClO}_{4}^{-}$농도가 감소하지 않고 배양액 내에 약 $10.3 \mathrm{mg} \mathrm{ClO}{ }_{4}^{-} / 1$ 가 잔존하는 경향을 나타냈다.

황을 산화해서 $\mathrm{ClO}_{4}^{-}$를 분해하는 공정은 $\mathrm{ClO}_{4}^{-}$가 제거됨에 따라 $\mathrm{H}^{+}$가 생성됨으로써 $\mathrm{pH}$ 가 낮아진다(식 3). 그래서 본 회 분배양실험 동안 반응기 내의 배양액 $\mathrm{pH}$ 를 분석하였다(Fig. $2 \mathrm{~B})$. 본 실험 조건 하에서 모든 반응기 내의 배양액 $\mathrm{pH}$ 는 배양 시간이 지남에 따라 감소하는 경향을 나타내었다. 초기 $\mathrm{pH}$ 가 7.43 와 8.23 인 경우는 배양말기인 23 일째에 $\mathrm{pH}$ 가 6.5 와 6.8 로 각각 감소하였다. 특히 초기 $\mathrm{pH}$ 6.35인 반응기는 배양 22 일째 에 $\mathrm{pH} 3.5$ 로 떨어짐에 따라 더욱 미생물의 활성을 저해시켜 $\mathrm{ClO}_{4}^{-}$분해에 영향을 주었으리라 추측된다. 본 실험을 통해 초기 $\mathrm{pH}$ 가 활성슬러지 내 $\mathrm{PRB}$ 의 $\mathrm{ClO}_{4}^{-}$분해활성에 영향을 준다는 것을 알 수가 있었고, 원소황이 산화됨에 따라 $\mathrm{H}^{+}$가 생 성됨을 감안해서 초기 $\mathrm{pH}$ 를 중성 또는 약 염기성 범위로 조절 해서 $\mathrm{ClO}_{4}{ }^{-}$의 분해를 도모할 필요가 있다는 것을 알 수 있다.

배양액의 초기 $\mathrm{pH}$ 가 $\mathrm{PRB}$ 의 $\mathrm{ClO}_{4}^{-}$분해활성에 영향을 미친 다는 것은 다른 문헌에서도 보고되었다. Acetate를 전자공여 체로 이용하는 농화배양된 활성슬러지를 사용하여 초기 $\mathrm{pH}$ $7-8$ 일 때 분해활성이 가장 우수했고 $\mathrm{pH}$ 6과 10 일 경우는 활성 이 현저히 저해되었다고 보고하였다[20].

\section{초기 $\mathrm{ClO}_{4}{ }^{-}$의 농도 효과}

회분배양실험에서 배양액의 초기 $\mathrm{ClO}_{4}^{-}$농도에 따른 $\mathrm{ClO}_{4}^{-}$ 생분해에 대한 영향을 조사하였다. 초기 $\mathrm{ClO}_{4}^{-}$의 농도를 14.07 , 23.37 그리고 $37.91 \mathrm{mg} / 1$ 로 각각 달리한 반응기의 배양액내의
$\mathrm{ClO}_{4}^{-}$농도를 주기적으로 분석하였다(Fig. 3). 배양 후 15 일 전 까지는 초기 $\mathrm{ClO}_{4}^{-}$의 농도가 $37.91 \mathrm{mg} / 1$ 일 때 단위시간당 $\mathrm{ClO}_{4}^{-}$제거량이 가장 많았으며 초기 $\mathrm{ClO}_{4}^{-}$의 농도가 14.07 $\mathrm{mg} / 1$ 일 때 단위시간당 $\mathrm{ClO}_{4}^{-}$제거량이 가장 적었다. 배양 후 15 일 이후에는 $\mathrm{ClO}_{4}^{-}$제거속도가 빠른 것은 $\mathrm{ClO}_{4}^{-}$의 농도가 $37.91,23.37$, 그리고 $14.07 \mathrm{mg} / 1$ 순으로 나타났다. 본 실험조건 에서 초기농도가 $14.07 \mathrm{mg} \mathrm{ClO}{ }_{4}^{-} / 1$ 인 경우는 $\mathrm{PRB}$ 개체군의 성장에 필요한 충분한 농도의 전자수용체가 존재하지 않아 $\mathrm{PRB}$ 의 성장이 느림에 따라 초기에 $\mathrm{ClO}_{4}^{-}$제거가 비교적 잘 되지 않은 것으로 여겨진다.

\section{접종균의 농도에 따른 효과}

접종균의 biomass 농도를 $0.02,0.04$ 그리고 $0.08 \mathrm{~g} \mathrm{VSS}$ 로 각각 달리하여 접종균의 biomass 농도가 $\mathrm{ClO}_{4}^{-}$분해에 미치는 영향을 조사하였다(Fig. 4). 활성슬러지를 접종균으로 이용한

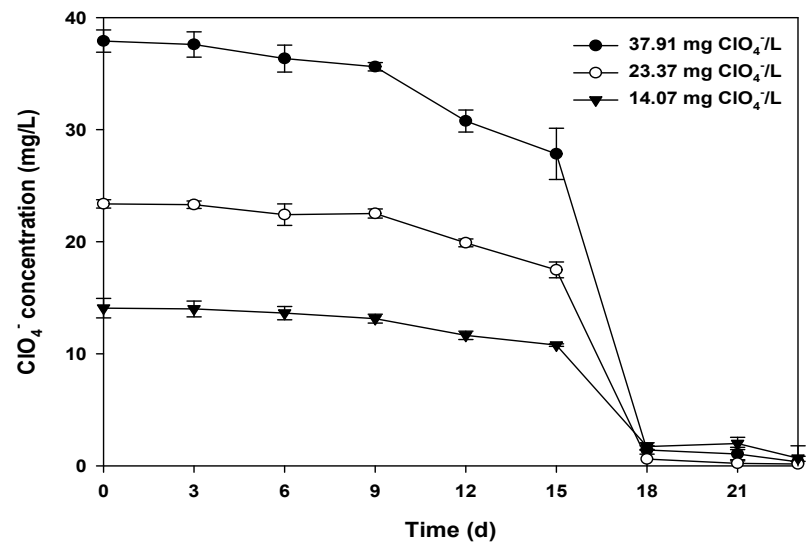

Fig. 3. Effect of initial perchlorate concentration on perchlorate removal by activated sludge in the presence of sulfur particles. Data are given as mean \pm standard deviation $(n=3)$. 

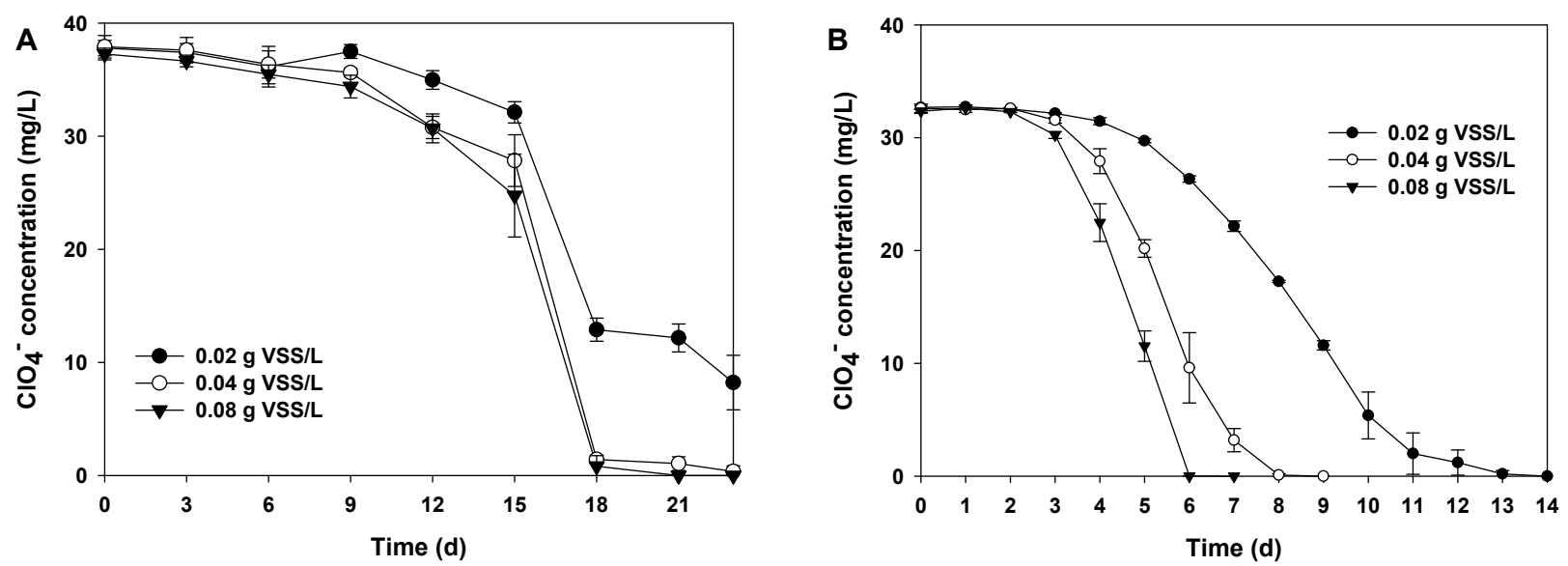

Fig. 4. Effect of initial biomass concentration on perchlorate removal by activated sludge (A) or enrichment culture (B) in the presence of sulfur particles. Data are given as mean \pm standard deviation $(n=3)$.

경우는 배양 12 일째까지는 초기 biomass 농도가 0.04 그리고 $0.08 \mathrm{~g} \mathrm{VSS} / 1$ 인 반응기는 거의 비슷한 $\mathrm{ClO}_{4}^{-}$제거효율을 나타 내었다(Fig. 4A). 이에 반해 초기 biomass 농도가 $0.02 \mathrm{~g} \mathrm{VSS} / 1$ 인 반응기는 비교적 $\mathrm{ClO}_{4}^{-}$제거효율이 매우 낮게 나타났다. 배양 15 일째 초기농도 $0.08 \mathrm{~g} \mathrm{VSS} / 1$ 인 반응기가 $0.04 \mathrm{~g} \mathrm{VSS} / 1$ 인 반응기보다 약간 제거효율이 증가하였으나 결국 18 일째는 $97.8 \%$ 와 $96.3 \%$ 의 제거효율을 각각 나타내어 거의 비슷한 경향 을 나타냈다. 반면에 초기 biomass 농도가 $0.02 \mathrm{~g} \mathrm{VSS} / 1$ 인 반 응기는 18 일째에 $12.9 \mathrm{mg} \mathrm{ClO}{ }_{4}^{-} / 1$ 가 반응기에 남아있어 제거 효율은 $65.9 \%$ 로 나타났다. 그 이후 약간의 농도감소가 있었으 나 23일까지 제거효율은 $78.3 \%$ 로 비교적 낮게 나타났다.

농화배양된 미생물을 접종하여 초기 biomass 농도가 $\mathrm{ClO}_{4}^{-}$ 분해에 미치는 영향도 조사하였다. 초기 biomass 농도가 0.08 $\mathrm{g} \mathrm{VSS} / 1$ 인 반응기는 배양 2 일째까지 잠복기를 나타내다가 배 양 3 일째부터 분해활성을 나타내기 시작하다가 배양 6 일째에 는 반응기내에 잔류하는 $\mathrm{ClO}_{4}^{-}$농도가 검출한계 이하로 나타 났다(Fig. 4B). 한편 초기 biomass 농도가 $0.04 \mathrm{~g} \mathrm{VSS} / 1$ 인 반응 기는 배양 8 일째에 $\mathrm{ClO}_{4}^{-}$분해를 완전히 한 것으로 나타났다. 반면에 초기 biomass 농도가 $0.02 \mathrm{~g} \mathrm{VSS} / 1$ 인 반응기는 배양 4 일째까지 잠복기를 나타내다가 그 이후 서서히 $\mathrm{ClO}_{4}^{-}$농도가 감소하다가 배양 13 일째에 완전분해가 되었다.

\section{접종균의 종류에 따른 효과}

접종균의 종류에 따른 $\mathrm{ClO}_{4}^{-}$분해에 대한 영향을 조사하였 다. Fig. 4 의 $\mathrm{A}$ 와 $\mathrm{B}$ 를 비교하면 배양초기에 같은 biomass 농도 로 반응을 시작하여도 접종균의 종류에 따라 $\mathrm{ClO}_{4}^{-}$제거효율 이 다르고, 농화배양된 미생물을 접종했을 때 더 분해가 잘 일어남을 알 수 있었다. 이러한 실험결과를 통해 본 연구에 사용된 농화배양액에는 PRB가 상당히 농화되어 있음을 짐작 할 수 있었다. 한편 활성슬러지를 접종균으로 사용하였을 때 $\mathrm{ClO}_{4}^{-}$농도변화가 관찰되지 않는 잠복기(lag time)가 비교적
길게 나타난 것은 농화배양액보다 PRB농도가 낮기 때문인 것 으로 여겨진다. $\mathrm{PRB}$ 농도가 비교적 높고 황과 $\mathrm{ClO}_{4}^{-}$에 이미 순응된 농화배양미생물을 접종균으로 활용한 경우 이러한 기 간을 줄일 수 있다는 것이 실험적으로 증명되었다. $\mathrm{ClO}_{4}^{-}$분해 능으로 보아 비교적 PRB 농도가 높을 것으로 여겨지는 농화배 양미생물을 접종했을 때에도 배양초기에 여전히 잠복기가 관 찰되었다. 이것은 원소 황의 물에 대한 용해도가 매우 낮아 미생물이 그것을 전자공여체로 이용하여 성장하는데 제한이 있거나 미생물의 순응(acclimation)에 필요한 잠복기인 것으 로 여겨진다.

\section{감사의 글}

이 논문은 2010년도 정부(교육과학기술부)의 재원으로 한 국연구재단의 기초연구사업(No. 2010-0006089)에서 지원을 받아 수행되었습니다.

\section{References}

1. APHA. 1995. Standard methods for examination of water and wastewater. 19th eds. American Public Health Association, Washington, D. C., USA.

2. Coates, J. D. and Achenbach, L. A. 2004. Microbial perchlorate reduction: Rocket-fuelled metabolism. Nat ReV Microbiol 2, 569-580.

3. Han, K. -R., Kang, T.-H., Kang, H.-C., Kim, K., Seo, D. -H. and Ahn, Y. 2011. Autotrophic perchlorate-removal using elemental sulfur granules and activated sludge: batch test. J Life Sci 21, 1473-1480.

4. Interstate Technology Regulatory Council (ITRC). 2005. Perchlorate: Overview of issues, status, and remedial options. http:/ / www.itrcweb.org/Documents/PERC-1.pdf

5. Ju, X., Sierra-Alvareza, R., Field, J. A., Byrnes, D. J., Bentley, H. and Bentley, R. 2008. Microbial perchlorate reduction 
with elemental sulfur and other inorganic electron donors. Chemosphere 71, 114-122.

6. Kim, H., Kim, J. and Lee, Y. 2007. Occurrence of perchlorate in drinking water in Korea. J Korean Soc Water Quality 23, 822-828.

7. Kim, H., Kim, J., Lee, Y., Lee, J. and Kim, S. 2008. Perchlorate in advanced drinking water treatment process. J Korean Soc Water Quality 24, 164-168.

8. Lee, C. 2009. Optimum treatment of sewage and wastewater discharged in Gumi industrial complex. Final report 09-2-10-16-5. Gyeongbuk regional environment technology development center. Gyeongbuk, Korea.

9. Lee, K., Kim, S., Lee, K. and Kwon, O. 2010. Biological treatment of perchlorate in inorganic wastewater from primary zinc smelting industry. Proceedings of Kor. Soc. on Water Quality April 16. Taejon, Korea. 103-104.

10. Logan, B. E. 1998. A review of chlorate-and perchlorate-respiring microorganisms. Bioremediation J 2, 69-79.

11. Miller, J. P. and Logan, B. E. 2000. Sustained perchlorate degradation in an autographic, gas-phase, packed-bed bioreactor. Environ Sci Technol 34, 3018-3022.

12. Min, B., Evans, P. J., Chiu, A. K. and Logan, B. E. 2004. Perchlorate removal in sand and plastic media bioreactors. Water Res 38, 47-60.
13. Motzer, W. E. 2001. Perchlorate: problems, detection, and solutions. Environ Forensics 2, 301-311.

14. National Research Council. 2005. Health implications of perchlorate ingestion. National Academy of Sciences. Washington, D. C., USA

15. Republic of Korea Ministry of Environment. 2007. Notice on amendment of law relating to conservation of water quality and water ecosystem. Notice No. 2007-419.

16. Republic of Korea Ministry of Environment. 2010. Guideline for the management of drinking water quality monitoring items.

17. Shin, K. -H., Son, A., Cha, D. K. and Kim, K.-W. 2007. Review on risks of perchlorate and treatment technologies. J Korean Soc Environ Eng 29, 1060-1068.

18. Snaider, J., Amann, R., Huber, I., Ludwig, W. and Schleifer, K. H. 1997. Phylogenetic analysis and in situ identification of bacteria in activated sludge. Appl Environ Microbiol 63, 2884-396.

19. US EPA. 1999. EPA METHOD 314.0: Determination of perchlorate in drinking water using ion chromatography.

20. Wu, D., He, P., Xu, X., Zhou, M., Zhang, Z. and Houda, $Z$. 2008. The effect of various reaction parameters on bioremediation of perchlorate-contaminated water. I Hazard Mater 150, 419-423.

\section{초록 : 원소 황 입자와 활성슬러지를 이용한 퍼클로레이트 제거특성}

한경림 ${ }^{1,2} \cdot$ 안영희 ${ }^{1} \star$

(동아대학교 환경공학과, ${ }^{2}$ 기초과학지원연구원 부산센터)

퍼클로레이트 $\left(\mathrm{ClO}_{4}\right)^{-}$는 지표수 및 토양/지하수에서 검출되는 신규 오염물이다. 퍼클로레이트 환원세균(PRB)은 $\mathrm{ClO}_{4}^{-2}$ 를 무해한 최종산물로 전환시킬 수 있으므로 $\mathrm{ClO}_{4}^{-}$제거는 미생물을 이용한 방법이 가장 적절한 것으로 알 려졌다. 이전 연구[3]를 통해 원소 황 입자와 활성슬러지를 이용하여 독립영양방식의 $\mathrm{ClO}_{4}^{-}$제거가 가능하다는 실험적 증거가 제시되었다. 입자상 황은 비교적 값이 저렴하고, 활성슬러지는 하수처리장으로부터 쉽게 구할 수 있는 장점이 있다. 그래서 본 연구에서는 원소 황을 전자공여체로 사용하였을 때 여러 환경요인이 활성슬러지 미생물의 $\mathrm{ClO}_{4}^{-}$분해에 미치는 영향을 회분반응으로 조사하였다. 이 회분반응의 결과를 통해 활성슬러지 미생물 에 의한 독립영양방식의 $\mathrm{ClO}_{4}^{-}$분해를 위한 최적조건을 도출하였다. 또한 활성슬러지로부터 농화배양된 황산화 $\mathrm{PRB}$ 는 활성슬러지보다 $\mathrm{ClO}_{4}^{-}$제거능이 우수한 것으로 회분반응 결과 나타났다. 그래서 본 연구결과는 최적조건 적용 및 농화배양된 접종균을 통해 원소 황과 활성슬러지를 이용한 독립영양방식의 $\mathrm{ClO}_{4}^{-}$제거를 향상할 수 있다 는 것을 나타내었다. 